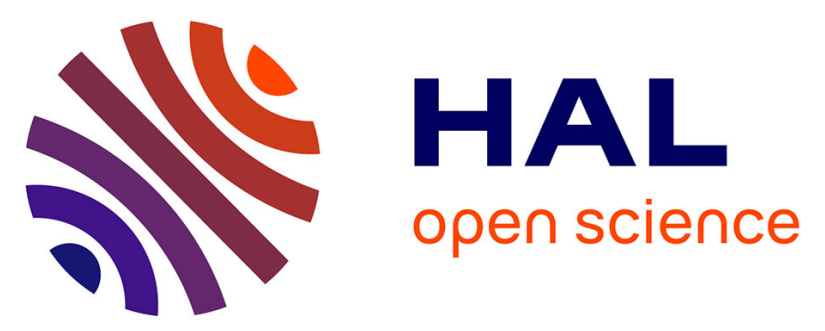

\title{
Pharmacogenomic adaptation of antiretroviral therapy: overcoming the failure of lopinavir in an African infant with CYP2D6 ultrarapid metabolism
}

Matthias Gorny, Stephanie Röhm, Stephanie Läer, Nezihe Morali, Tim Niehues

\section{To cite this version:}

Matthias Gorny, Stephanie Röhm, Stephanie Läer, Nezihe Morali, Tim Niehues. Pharmacogenomic adaptation of antiretroviral therapy: overcoming the failure of lopinavir in an African infant with CYP2D6 ultrarapid metabolism. European Journal of Clinical Pharmacology, 2009, 66 (1), pp.107108. 10.1007/s00228-009-0753-1 . hal-00537992

\section{HAL Id: hal-00537992 https://hal.science/hal-00537992}

Submitted on 20 Nov 2010

HAL is a multi-disciplinary open access archive for the deposit and dissemination of scientific research documents, whether they are published or not. The documents may come from teaching and research institutions in France or abroad, or from public or private research centers.
L'archive ouverte pluridisciplinaire $\mathbf{H A L}$, est destinée au dépôt et à la diffusion de documents scientifiques de niveau recherche, publiés ou non, émanant des établissements d'enseignement et de recherche français ou étrangers, des laboratoires publics ou privés. 


\title{
Pharmacogenomic adaptation of antiretroviral therapy: overcoming the failure of lopinavir in an African infant with CYP2D6 ultrarapid metabolism
}

\author{
Matthias Gorny • Stephanie Röhm • Stephanie Läer • \\ Nezihe Morali • Tim Niehues
}

Received: 25 October 2009 / Accepted: 27 October 2009 / Published online: 20 November 2009

(C) Springer-Verlag 2009

Keywords CYP2D6 $\cdot$ Lopinavir $\cdot$ Ritonavir $\cdot$ Antiretroviral therapy · HAART

\section{Case report}

We report the case of a 6-month-old, HIV-positive girl of black Congolese origin who failed to respond to highly active antiretroviral therapy (HAART) over a period of 3 months. HAART included lopinavir in a fixed combination with ritonavir (Kaletra ${ }^{\circledR}$ suspension, Abbott Laboratories), as well as abacavir, lamivudine, and nevirapine. Therapy was given in accordance with pediatric guidelines for use of the antiretroviral agents [1]. Lack of adherence during the patient's hospitalization can be ruled out as a cause of nonresponse.

To assess the cause of treatment failure, trough plasma concentrations of protease inhibitors and nevirapine were determined at steady state. Lopinavir and ritonavir were not detectable, whereas the plasma concentration of nevirapine

M. Gorny $\cdot$ S. Röhm · S. Läer $(\bowtie)$

Department of Clinical Pharmacy and Pharmacotherapy,

Heinrich-Heine-University Düsseldorf,

Universitätsstrasse 1,

40225 Düsseldorf, Germany

e-mail: Stephanie.Laeer@uni-duesseldorf.de

N. Morali $\cdot$ T. Niehues

Department of Paediatric Oncology,

Haematology and Immunology, Düsseldorf University Hospital,

Düsseldorf, Germany

T. Niehues

Centre for Child and Adolescent Health, Helios Klinikum Krefeld,

Krefeld, Germany was within the expected range. Increasing the dosage of lopinavir and ritonavir to a maximum of $180 \mathrm{mg} / 45 \mathrm{mg}$, respectively, twice a day did not result in detectable plasma levels. Thus, we hypothesized that treatment failure may be due to increased ritonavir metabolism.

Lopinavir is metabolized predominantly by cytochrome P450 (CYP) 3A4 and is subject to a potent first-pass effect, resulting in very poor bioavailability [2]. Thus, lopinavir is licensed only in combination with ritonavir, which inhibits CYP3A4 and thereby increases bioavailability. Ritonavir is metabolized mainly by CYP3A4 and to a lesser but clinically relevant extent by CYP2D6 [3]. CYP2D6 activity shows very high interindividual variability, primarily due to differences among patients in genetic polymorphisms. Of note, up to $16 \%$ of the African population, to which our patient belongs, are CYP2D6 ultrarapid metabolizers (UMs) [4], resulting in a potent accelerated metabolism for substrates of this enzyme (Fig. 1).

We performed CYP2D6 genotyping in our patient and confirmed that she was indeed a UM for CYP2D6. Consequently, ritonavir in this patient was subject to accelerated metabolism and had no inhibitory effect on the CYP3A4-mediated first-pass metabolism of lopinavir. To effectively inhibit CYP3A4, we increased the ritonavir dosage threefold (Norvir ${ }^{\circledR}$ suspension, Abbott Laboratories) to $150 \mathrm{mg}$ twice daily (equivalent to $2 \times 25.5 \mathrm{mg} / \mathrm{kg}$ or $2 \times 512.1 \mathrm{mg} / \mathrm{m}^{2}$ ). This was an empirical approach in the absence of explicit guidelines, nevertheless resting upon CYP2D6 genotype-based dosing recommendations for antidepressants [5]. To avoid adverse reactions from high lopinavir concentrations, such as lipid metabolic disorder and elevated alanine transaminase (ALT), aspartate transaminase (AST), and gamma-glutamyl transpeptidase (gammaGT) activity, the dosage of lopinavir and ritonavir combined 
Fig. 1 Pharmacokinetic interaction between ritonavir and lopinavir. Due to the fact that the patient belongs to the group of ultrarapid metabolizers (UMs) for cytochrome (CYP) 2D6, the usual dosage of ritonavir was too low to reach detectable plasma levels and inhibit CYP3A4. After changing the dosage based on pharmacogenomic analysis (day 109 of the hospital stay), plasma levels of ritonavir and lopinavir became detectable on day 123 of the hospital stay

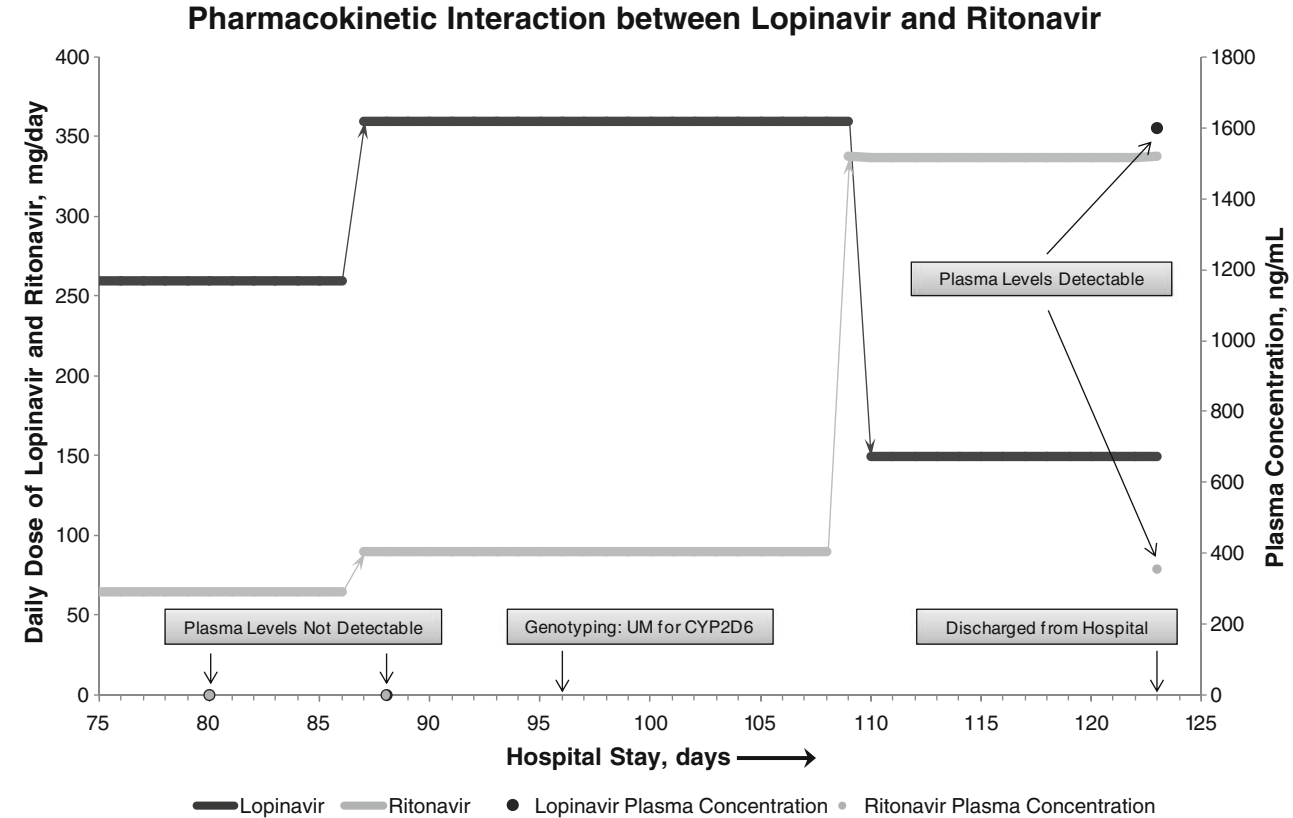

in Kaletra ${ }^{\circledR}$ was decreased to $75 \mathrm{mg} / 19 \mathrm{mg}$ twice daily (equal to $234 \mathrm{mg} / \mathrm{m}^{2}$ and $59 \mathrm{mg} / \mathrm{m}^{2}$, respectively). The trough plasma levels of ritonavir and lopinavir were quantified again 14 days after switching therapy (day 123 of the hospital stay) and reached concentrations of $356 \mathrm{ng} / \mathrm{ml}$ and $1,600 \mathrm{ng} / \mathrm{ml}$, respectively (Fig. 1). At this dosing level, ritonavir is likely to inhibit CYP3A4 due to a detectable plasma concentration of lopinavir despite a reduced dosage.

On day 6 of the pharmacogenomic adaptation of the regimen (day 115 of the hospital stay), the viral load of HIV-1-RNA decreased from $1.2 \times 10^{6}$ copies/ml to approximately 8,000 copies $/ \mathrm{ml}$ in blood. Lamivudine was replaced by zidovudine 7 days before pharmacogenomic dose adaption without improvement of clinical symptoms, and it appears highly unlikely that this replacement caused the massive viral-load reduction. It is much more likely that the protease inhibitor lopinavir, which now reached adequate plasma levels, was associated with viral-load reduction. No increase in ALT or AST activity, or cholesterol and triglyceride levels during the pharmacogenomically adapted therapy was observed.

As a consequence of CYP2D6 genotyping, it was possible to optimize this patient's therapy. Pharmacogenomic adaptation and optimization of antiretroviral therapy is likely to be highly clinically relevant in the treatment of
HIV-infected patients of African descent, especially due to the prevalence of HIV infection and the high proportion of CYP2D6 UMs in this population.

\section{References}

1. Niehues T, Baumann U, Buchholz B et al (2006) Empfehlungen zur antiretroviralen Therapie bei HIV-infizierten Kindern - KonsensusStatement der Pädiatrischen Arbeitsgemeinschaft AIDS (PAAD) und der Deutschen Gesellschaft für Pädiatrische Infektiologie (DGPI). Mon.schr Kinderheilkd 154:565-577

2. Kumar GN, Dykstra J, Roberts EM et al (1999) Potent inhibition of the cytochrome P-450 3A-mediated human liver microsomal metabolism of a novel HIV protease inhibitor by ritonavir: A positive drug-drug interaction. Drug Metab Dispos 27:902-908

3. Kumar GN, Rodrigues AD, Buko AM, Denissen JF (1996) Cytochrome P450-mediated metabolism of the HIV-1 protease inhibitor ritonavir (ABT-538) in human liver microsomes. J Pharmacol Exp Ther 277:423-431

4. Ingelman-Sundberg M (2005) Genetic polymorphisms of cytochrome P450 2D6 (CYP2D6): clinical consequences, evolutionary aspects and functional diversity. Pharmacogenomics J $5: 6-13$

5. Kirchheiner J, Brøsen K, Dahl ML et al (2001) CYP2D6 and CYP2C19 genotype-based dose recommendations for antidepressants: a first step towards subpopulation-specific dosages. Acta Psychiatr Scand 104:173-192 